\title{
A Green Protocol for Efficient Synthesis of 1,8-Dioxo-Octahydroxanthenes Using Ionic Liquid
}

\author{
Sangita Makone*, Shreyas Mahurkar \\ Chemical Sciences Research Laboratory, School of Chemical Sciences, \\ Swami Ramanand Teerth Marathwada University, Nanded, India \\ Email: *ss_makone@rediffmail.com
}

Received October 31, 2013; revised November 20, 2013; accepted November 27, 2013

Copyright (C) 2013 Sangita Makone, Shreyas Mahurkar. This is an open access article distributed under the Creative Commons Attribution License, which permits unrestricted use, distribution, and reproduction in any medium, provided the original work is properly cited.

\begin{abstract}
A clean, simple, efficient synthesis of 1,8-dioxo-octahydroxanthenes derivatives using ionic liquid 1-butyl, 3-methylimidazolium perchlorate $\left([\mathrm{bmim}] \mathrm{ClO}_{4}\right)$ has been developed. The method provides several advantages such as simple work up, environmental friendliness and excellent yields in short reaction time. The ionic liquid $[\mathrm{bmim}] \mathrm{ClO}_{4} \mathrm{used}$ was recovered and reused for three times.
\end{abstract}

Keywords: 1,8-Dioxo-Octahydroxanthenes; Ionic Liquid; Aldehydes; Dimedone

\section{Introduction}

1,8-dioxo-octahydroxanthenes are important class of oxygen heterocycles in which a phenyl substituted pyran ring is fused on either side with two cyclohexanone rings. Presence of conjugated bis-dienone functionality makes these compounds sensitive to be attacked by nucleophiles and light energy. In the past decade, synthesis of xanthenes derivatives has been of considerable interest to organic chemists because they possess various biological and pharmaceuticals activities such as antiviral [1], antibacterial [2] and anti-inflammatory [3] properties. These are being utilized as antagonists for paralyzing action of zoxazolamine [4] and in photodynamic therapy [5]. Xanthenes and benzoxanthenes derivatives are the parent frame works found in a large number of naturally occurring as well as synthetic products possessing prominent position in medicinal chemistry [6,7]. Xanthenediones are likewise special structural units constituting various natural products [8] and being used as versatile synthons, because of inherent reactivity of their inbuilt pyran ring [9].

Apart from their use as valuable synthetic precursors for many organic compounds [10] and dyes [11], they are also used in laser technologies [12] and $\mathrm{pH}$-sensitive fluorescent materials for the visualization of biomolecules assemblies [13].

"Corresponding author.
There are a wide variety of methods for the preparation of the xanthenes having been reported and they are classified according to starting compounds which includes synthesis by cyclization of polycyclic aryltiflate esters [14], intra-molecular trapping of benzynes by phenols [15] and reaction of aryloxy magnesium halides with triethyl orthoformate [16] as well as cyclo-condensation of 2-hydroxyl aromatic aldehyde with 2-tetralone [17].

One of the commonly used methods reported for the synthesis of xanthenediones involves the condensation of aromatic aldehydes with 1,3-cyclohexanedione or 5,5dimethyl-1, 3-cyclohexanedione. The various catalysts have been reported for synthesis of 1,8-dioxo-octahydroxanthens: NSPVPC [18], [ $\left.\mathrm{Et}_{3} \mathrm{NH}\right]\left[\mathrm{HSO}_{4}\right.$ ] [19], $\mathrm{SiCl}_{4}$ [20], $\left[\mathrm{Et}_{3} \mathrm{NC}_{4} \mathrm{SO}_{3} \mathrm{H}\right]\left[\mathrm{HSO}_{4}\right] / \mathrm{Al}_{2} \mathrm{O}_{3}$ [21], polyaniline p-toluenesulfonate [22], alumina-sulfuric acid [23], CAN [24], [BMIm] $\left[\mathrm{BF}_{4}\right]-\mathrm{Mg}\left(\mathrm{BF}_{4}\right)$ [25], $\mathrm{I}_{2}$ [26], [ $\left.\mathrm{Et}_{3} \mathrm{~N}-\mathrm{SO}_{3} \mathrm{H}\right] \mathrm{Cl}$ [27], DABCO [28], $\mathrm{SmCl}_{3}$ [29], cellulose sulfonic acid [30], heteropolyacid-MCM-41 i.e. $\left(\mathrm{H}_{3} \mathrm{PW}_{12} \mathrm{O}_{40}\right)$ [31], [bmim] $\mathrm{HSO}_{4}$ [32], $\mathrm{Fe}\left(\mathrm{HSO}_{4}\right)_{3}$ [33], [Hbim] $\mathrm{BF}_{4}$ [34], TBAHS [35] tetramethylguanidium trifluoroacetate [36], [DDPA] [ $\mathrm{HSO}_{4}$ ] [37], [TMPSA] $\mathrm{HSO}_{4}$ [38], [Hmim] TFA [39], trichloro isocyanuric acid [40], $\mathrm{SbCl}_{3} / \mathrm{SiO}_{2}$ [41], $\mathrm{SiO}_{2}-\mathrm{R}$ $\mathrm{SO}_{3} \mathrm{H}$ [42], $\mathrm{InCl}_{3} / \mathrm{P}_{2} \mathrm{O}_{5}$ [43], p-dodecyl benzenesulfonic acid [44], triethyl benzyl ammonium chloride (TEBA) [45], diammonium hydrogen phosphate [46], $\mathrm{PPA}-\mathrm{SiO}_{2}$ [47], montmorillonite $\mathrm{K}-10$ [48], $\mathrm{Fe}^{3+}$-Montmorillonite 
[49], trimethyl silyl chloride [50], $\mathrm{NaHSO}_{4}-\mathrm{SiO}_{2}$ [51], $\mathrm{ZnO}$-Acetyl chloride [52], $\mathrm{PMA}_{-} \mathrm{SiO}_{2}$ [53], $\mathrm{ZrOCl}_{2} \cdot 8 \mathrm{H}_{2} \mathrm{O}$ [54], Amberlyst-15 [55], Dowex-50W [56]. Most of these methods have some advantages and disadvantages, taking the weakness into consideration such as long reaction time, low yields, use of hazardous catalysts and solvents, tedious work up processes and difficulty in recovery and reusability of catalyst. To overcome these problems we have developed the green protocol for efficient synthesis of 1,8-dioxo-octahydroxanthenes using [bmim $] \mathrm{ClO}_{4}$ ionic liquid (Scheme 1).

In recent years, ionic liquids have emerged as a useful alternative to conventional organic solvents and catalysts due to their particular properties, such as negligible vapor pressure, chemical stability, excellent solvent power for organic and inorganic compounds, as well as the ease of recovery [57]. Recently, much attention has been paid to organic reactions carried by using ionic liquids greater than ever importance in the context of green synthesis. Although ionic liquids were primarily introduced as an alternative green reaction medium, today they have progressed extremely beyond that, playing a significant role in controlling reactions as catalysts.

\section{Experimental Procedure}

All the chemicals were purchased from Sigma Aldrich and Merck chemicals. Melting points recorded on Veego melting point apparatus and were uncorrected. ${ }^{1} \mathrm{H}$ NMR spectra were recorded on a Brucker Avance II $400 \mathrm{MHz}$ spectrometer with TMS as internal standard. IR spectra were determined on Perkin Elmer Spectrum RX FTIR spectrometer. The ionic liquid was synthesized according to ref. [58].

\section{General Procedure for Synthesis of 1,8-Dioxo-Octahydroxanthens Derivatives}

To a mixture of aldehyde $(1 \mathrm{mmol})$ and 5,5-dimethyl1,3 -cyclohexanedione $(2 \mathrm{mmol})$ and $[\mathrm{bmim}] \mathrm{ClO}_{4}(4$ mmol) was added in $50 \mathrm{ml}$ round bottom flask and was stirred at $100^{\circ} \mathrm{C}$ on heating magnetic stirrer (Scheme 1). The progress of the reaction was monitored by TLC after completion of the reaction the reaction mixture was cooled to room temperature and water $(5 \mathrm{ml})$ was added, solid separated was filtered. The crude product was recrystallized from ethanol to give the pure product. The [bmim $] \mathrm{ClO}_{4}$ was recovered by distillation and reused 3 times.

The comparison of various reported catalyst is summarized in (Table 1).

3,3,6,6-tetramethyl-9-(4-chloro-phenyl)-1,8-dioxooctahydroxanthene (Entry 1) IR $\left(\mathrm{cm}^{-1}\right)$ : 3030, 2963, 2952, 1679, 1661, 1469, 1361, 1198, 1166, 1003, 852. 1H NMR: 7.17 - 7.24 (dd, 4H), 4.71 (s, 1H), 2.46 (s, 4H), $2.18(\mathrm{q}, 4 \mathrm{H}), 1.10(\mathrm{~s}, 6 \mathrm{H}), 0.98(\mathrm{~s}, 6 \mathrm{H}) .13 \mathrm{C}$ NMR: $191.10,157.17,137.45,126.79,124.53,122.97,110.03$, 45.45, 35.61, 26.96, 26.22, 24.03, $22.05 \mathrm{~m} / \mathrm{z}: 385.2(\mathrm{M}+$ 1), 273.2 .

3,3,6,6-tetramethyl-9-(4-methyl-phenyl)-1,8-dioxooctahydroxanthene (Entry 2) IR $\left(\mathrm{cm}^{-1}\right)$ : 3036, 2959, 2873, 1663, 1623, 1359, 1197, 1164, 1139, 1000, 842. 1H NMR: 7.17 (d, 2H), 7.01(d, 2H), 4.71(s, 1H), 2.45 (s, 4H), 2.24 (s, 3H), 2.18 (q, 4H), 1.09 (s, 6H), 0.99 (s, 6H). 13C NMR: 196.4, 162.0, 141.1, 135.7, 128.7, 128.2, 115.7, 50.7, 40.8, 32.2, 31.4, 29.2, 27.3, 21.0. m/z: 365.3 $(\mathrm{M}+1), 273.2$.

9,9'-(1,4-phenylene)bis(3,3,6,6-tetramethyl-3,4,5,6,7, 9-hexahydro-1H-xanthene-1,8 (2H)-dione (Entry 4) IR $\left(\mathrm{cm}^{-1}\right): 2957,2871,1665,1620,1365,1201,1167,1144$, 1005, 590. 1H NMR: 7.07 (s, 4H), $4.70(\mathrm{~s}, 2 \mathrm{H}), 2.42(\mathrm{~s}$, $8 \mathrm{H}), 2.17$ (s, 8H), 1.07 (s, 12H), 0.97 (s, 12H). m/z: 13C NMR: 196.4, 162.4, 141.7, 127.9,115.7, 50.8, 40.8, 32.2, 30.1, 28.9, 27.7. m/z: 645.4 (M+Na), 273.2.

3,3,6,6-tetramethyl-9-(4-hydroxy-3-methoxy-phenyl)1,8-dioxo-octahydroxanthene (Entry 5) IR $\left(\mathrm{cm}^{-1}\right)$ : 3412, 3029, 2954, 1666, 1622, 1514, 1431, 1359, 1278, 1229, 1197, 1135, 1028, 624, 571. 1H NMR: 7.01 (s, 1H), $6.73(\mathrm{~d}, 1 \mathrm{H}), 6.56(\mathrm{dd}, 1 \mathrm{H}), 5.49(\mathrm{bs}, 1 \mathrm{H},-\mathrm{OH}), 4.66(\mathrm{~s}$, $1 \mathrm{H}), 3.89$ (s, 3H), 2.45 (s, 4H), 2.20 (q, 4H), 1.00 (s, 12H). 13C NMR: 196.6, 162.0, 145.8, 144.0, 136.4, $120.0,115.8,113.9,112.2,55.8,50.7,40.8,32.2,31.3$, 29.3, 27.2. $\mathrm{m} / \mathrm{z}: 396.47,419.3(\mathrm{M}+\mathrm{Na}), 273.2$.

3,3,6,6-tetramethyl-9-(4-methoxy-phenyl)-1,8-dioxooctahydroxanthene (Entry 7) IR $\left(\mathrm{cm}^{-1}\right): 3059,2958$, 2876, 1665, 1626, 1511, 1462, 1357, 1260, 1193, 1109, 1031, 841, 569. 1H NMR: 7.18 (d, 2H), 6.75 (d, 2H), $4.69(\mathrm{~s}, 1 \mathrm{H}), 3.73(\mathrm{~s}, 3 \mathrm{H}), 2.45(\mathrm{~s}, 4 \mathrm{H}), 1.09(\mathrm{~s}, 6 \mathrm{H}), 0.99$ (s, 6H). 13C NMR: 196.5, 162.0, 157.9, 136.4, 129.3, 115.7, 113.4, 55.1, 50.7, 40.8, 32.2, 30.9, 29.2, 27.3. m/z: $381.2,273.2$.

\section{Result and Discussion}

To a mixture of 4-chloro benzaldehyde $(1 \mathrm{mmol})$ and 5,5-dimethyl-1,3-cyclohexanedione $(2 \mathrm{mmol})$ and [bmim] $\mathrm{ClO}_{4}(4 \mathrm{mmol})$ was added in $50 \mathrm{ml}$ round bottom flask and was stirred at $100^{\circ} \mathrm{C}$ on heating magnetic stirrer. The progress of the reaction was monitored by TLC After completion of the reaction the reaction mixture was cooled to room temperature and water $(5 \mathrm{ml})$ was added, solid separated was filtered and product was characterized by IR, NMR, ${ }^{13} \mathrm{C}-\mathrm{NMR}$ and mass.

The reaction between dimedone and 4-chloro benzaldehyde in the presence of $[\mathrm{bmim}] \mathrm{ClO}_{4}$ was studied as a model reaction. To optimize the reaction conditions of reaction temperature we have tried the study of above model reaction from temperature $60-110^{\circ} \mathrm{C}$ in the gap of $10^{\circ} \mathrm{C}$. The best result in terms of time and yield for the reaction has been observed at $100^{\circ} \mathrm{C}$ (Table 2). 


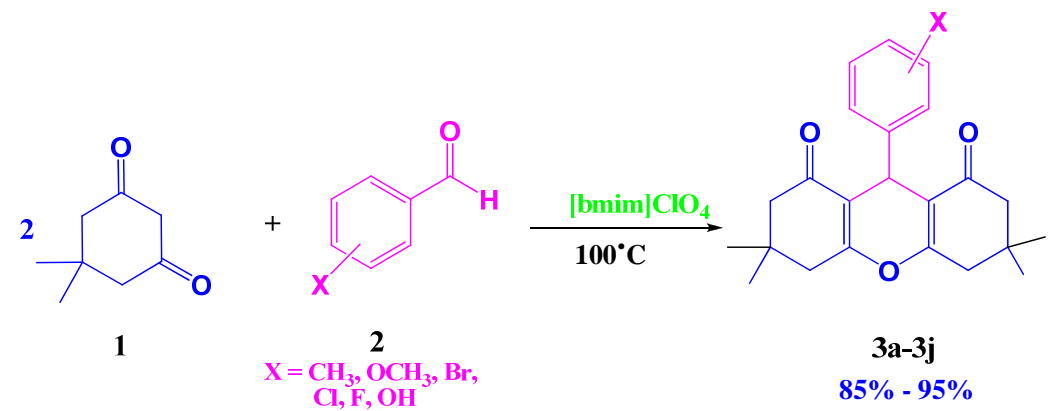

Scheme 1. Synthesis of 1,8-dioxo-octahydroxanthene using [bmim]ClO $\mathrm{b}_{4}$ ionic liquid.

Table 1. Comparison table with various reported catalysts.

\begin{tabular}{|c|c|c|c|c|c|c|}
\hline Entry & Catalyst used & Time & Solvent & Temperature & Yield (\%) & Ref. \\
\hline 1 & Tetrachloro silane & $3 \mathrm{hrs}$ & $\mathrm{CH}_{2} \mathrm{Cl}_{2}$ & $60-70^{\circ} \mathrm{C}$ & 92 & {$[20]$} \\
\hline 2 & $\mathrm{SmCl}_{3}$ & $8 \mathrm{hrs}$ & No solvent & $120^{\circ} \mathrm{C}$ & 98 & [29] \\
\hline 3 & Cellulose sulfonic acid & $6 \mathrm{hrs}$ & No solvent & $110^{\circ} \mathrm{C}$ & 95 & {$[30]$} \\
\hline 4 & Heteropoly acid supported MCM-41 & $5 \mathrm{hrs}$ & Ethanol & $90^{\circ} \mathrm{C}$ & 90 & {$[31]$} \\
\hline 5 & {$[\mathrm{Bmim}] \mathrm{HSO}_{4}$} & $3.5 \mathrm{hrs}$ & No solvent & $80^{\circ} \mathrm{C}$ & $76-94$ & {$[32]$} \\
\hline 6 & {$[\mathrm{Hbim}] \mathrm{BF}_{4}$} & $45 \mathrm{~min}$. & Methanol & $\begin{array}{l}\text { Ultrasonic } \\
25-30^{\circ} \mathrm{C}\end{array}$ & 85 & {$[34]$} \\
\hline 7 & Trimethyl silyl chloride & $8-10 \mathrm{hrs}$ & Acetonitrile & Reflux & $72-84$ & {$[50]$} \\
\hline 8 & {$[\mathrm{Bmim}] \mathrm{ClO}_{4}$} & $40-90 \mathrm{~min}$. & ---- & $100^{\circ} \mathrm{C}$ & $85-95$ & Present work \\
\hline
\end{tabular}

Table 2. Optimization of reaction temperature for synthesis of 1,8-dioxo-octahydroxanthenes.

\begin{tabular}{cccc}
\hline Entry & Temperature $\left(\right.$ in $\left.{ }^{\circ} \mathrm{C}\right)$ & Time (in hrs.) & Yields (in \%) \\
\hline 1 & 60 & $8 \mathrm{hrs}$ & 55 \\
2 & 70 & $6 \mathrm{hrs}$ & 70 \\
3 & 80 & $5 \mathrm{hrs}$ & 75 \\
4 & 90 & $2.5 \mathrm{hrs}$ & 85 \\
5 & 100 & $1 \mathrm{hr}$ & 94 \\
6 & 110 & $1 \mathrm{hr}$ & 94 \\
\hline
\end{tabular}

To evaluate the scope of this reaction a range of 1 , 8 -dioxo-octahydroxanthenes were prepared by the reaction of dimedone and aromatic aldehydes under optimized reaction conditions. The results are summarized in the table (Table 3). Various aromatic aldehydes with electron donating substituent's reacted efficiently and quickly with dimedone to give cyclocondensation products in high yields over short reaction times. Similarly aldehydes with electron withdrawing substituent's reacted efficiently to yield the corresponding 1,8-dioxooctahydroxanthenes.

Study of reuse of the ionic liquid can be easily done up to 3 times with excellent yields without loss in the reactivity (as shown in graph/Figure 1). After $3^{\text {rd }}$ cycle we observed sudden decrease in the $4^{\text {th }}$ reuse of ionic liquid thus the ionic liquid used was recycled for 3 times. The structure of isolated products was assigned based on their
Table 3. Green protocol for efficient synthesis of 1 , 8-dioxoxanthenes using $[\mathrm{bmim}] \mathrm{ClO}_{4}{ }^{\mathrm{a}}$

\begin{tabular}{|c|c|c|c|c|c|}
\hline Entry & Aldehyde & Product $^{\mathrm{b}}$ & $\begin{array}{l}\text { Time } \\
\text { (min.) }\end{array}$ & $\begin{array}{l}\text { Yield }^{\mathrm{c}} \\
(\%)\end{array}$ & $\mathrm{Mp} .\left({ }^{\circ} \mathrm{C}\right)$ \\
\hline 1 & $\begin{array}{c}\text { 4-Chloro } \\
\text { benzaldehyde }\end{array}$ & $3 a$ & 60 & 94 & $215-217$ \\
\hline 2 & $\begin{array}{c}\text { 4-Methyl } \\
\text { benzaldehyde }\end{array}$ & $3 b$ & 70 & 95 & $217-218$ \\
\hline 3 & Benzaldehyde & $3 c$ & 40 & 92 & $205-206$ \\
\hline 4 & Terephthaldehyde & $3 d$ & 90 & 88 & $>300$ \\
\hline 5 & Vanillin & $3 e$ & 50 & 85 & $225-227$ \\
\hline 6 & 4-Fluro benzaldehyde & $3 f$ & 50 & 92 & $232-233$ \\
\hline 7 & $\begin{array}{c}\text { 4-Methoxy } \\
\text { benzaldehyde }\end{array}$ & $3 g$ & 60 & 95 & $241-243$ \\
\hline 8 & $\begin{array}{c}\text { 3-Chloro } \\
\text { benzaldehyde }\end{array}$ & $3 \mathrm{~h}$ & 60 & 90 & $183-184$ \\
\hline 9 & $\begin{array}{c}\text { 4-Bromo } \\
\text { benzaldehyde }\end{array}$ & $3 \mathrm{i}$ & 60 & 90 & $222-224$ \\
\hline 10 & $\begin{array}{l}\text { 4-Hydroxy } \\
\text { benzaldehyde }\end{array}$ & $3 \mathrm{j}$ & 70 & 87 & $228-230$ \\
\hline
\end{tabular}

${ }^{\mathrm{a}}$ Reaction condition: aromatic aldehydes $(2 \mathrm{mmol}), 5,5$-dimethyl-1-3cyclohexanedione $(4 \mathrm{mmol}),[\mathrm{bmim}] \mathrm{ClO}_{4}(4 \mathrm{mmol})$ at $100^{\circ} \mathrm{C}$. ${ }^{\mathrm{b}} \mathrm{All}$ the product were characterized by IR spectral data and comparison of their melting point with those of the authentic samples. Also the structures of the some products were confirmed by $1 \mathrm{H}$ NMR spectral data. ${ }^{\circ}$ Isolated yield.

spectral analyses as well as by matching with their melting point with reported analogous. 


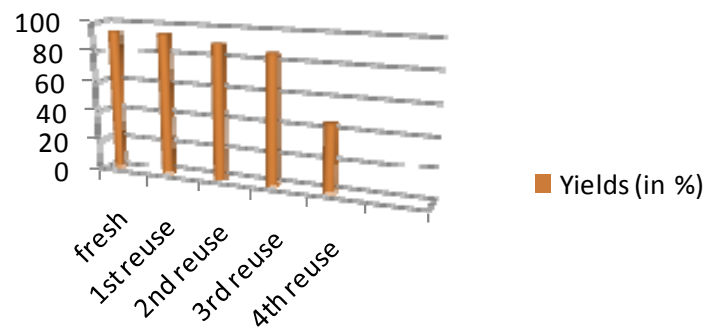

Figure 1. Study of reuse of ionic liquid.

\section{Conclusion}

In summary, we have developed a high-yielding simple, convenient, straight-forward and practical one-pot procedure for the synthesis of different types of 1,8-dioxooctahydroxanthenes derivatives using $[\mathrm{bmim}] \mathrm{ClO}_{4}$. The ionic liquid used can be easily recovered and reused 3 times without significant decrease in the yield of the product.

\section{REFERENCES}

[1] R. W. Lamberk, J. A. Martin, J. H. Merrett, K. E. B. Parkes and G. J. Thomas, PCT Int. Appl. WO 9706178, 1997, Chemical Abstract, Vol. 126, 1997, p. 212377y.

[2] T. Hideu, JPn. Tokkyo Koho JP 56005480, 1981, Chemical Abstract, Vol. 95, 1981, 80922b.

[3] J. P. Poupelin, G. Saint-Rut, O. Fussard-Blanpin, G. Narciss, G. U. Ernouf and R. Lakroix, "Synthesis and Antiinflammatory Properties of Bis (2-Hydroxy, 1-Naphthyl) Methane Derivatives," European Journal of Medicinal Chemistry, Vol. 13, 1978, pp. 67-71.

[4] G. Saint-Ruf, A. De and H. T. Hieu, "The Effect of Dibenzoxanthenes on the Paralyzing Action of Zoxazolamine," Naturwissenschaften, Vol. 62, No. 12, 1975, pp. 584-585. http://dx.doi.org/10.1007/BF01166986

[5] R. M. Ion, D. Frackowiak, A. Planner and K. Wiktorowicz, "The Incorporation of Various Porphyrins into Blood Cells Measured via Flow Cytometry, Absorption and Emission Spectroscopy," Acta Biochimica Polonica, Vol. 45, No. 3, 1998, pp. 833-845.

[6] H. K. Wang, S. L. Morris-Natschke and K. H. Lee, "Recent Advances in the Discovery and Development of Topoisomerase Inhibitors as Antitumor Agents," Medicinal Research Reviews, Vol. 17, No. 4, 1997, pp. 367-425. http://dx.doi.org/10.1002/(SICI)1098-1128(199707)17:4< 367::AID-MED3>3.0.CO;2-U

[7] A. V. Rukavishnikov, M. P. Smith, G. B. Birrell, J. F. W. Keana and O. H. Griffith, "Synthesis of a New Fluorogenic Substrate for the Assay of Phosphoinositide-Specific Phospholipase C," Tetrahedron Letter, Vol. 39, No. 37, 1998, pp. 6637-6640. http://dx.doi.org/10.1016/S0040-4039(98)01429-4

[8] S. Hatakeyma, N. Ochi, H. Numata and S. Takano, "A New Route to Substituted 3-Methoxycarbonyldihydropyrans; Enantioselective Synthesis of (-)-Methyl Elenolate," Journal of the Chemical Society, Chemical Com- munications, No. 17, 1988, pp. 1202-1204. http://dx.doi.org/10.1039/c39880001202

[9] C. N. O'Callaghan and T. B. H. McMurry, "Synthetic reactions of methyl XY-carbonyl-4H-1-benzopyran-4yl cyanoethanoate," Journal of Chemical Research, Synopses, 1995, pp. 214-218.

[10] Y. M. Shchekotikhin and T. G. Nikolaeva, "Transformations of Sym-Octahydroxanthene-1,8-Diones and 1,8-DioxoSym-Octahydroxanthylium Salts in Recyclization under the Influence of Amines," Chemistry Heterocyclic Compound, Vol. 42, No. 1, 2006, pp. 28-33. http://dx.doi.org/10.1007/s10593-006-0042-1

[11] S. A. Hilderbrand and R. Weissleder, "One-Pot Synthesis of New Symmetric and Asymmetric Xanthene Dyes," Tetrahedron Letter, Vol. 48, No. 25, 2007, pp. 4383-4385. http://dx.doi.org/10.1016/j.tetlet.2007.04.088

[12] G. Pohlers and J. C. Scaiano, "A Novel Photometric Method for the Determination of Photoacid Generation Efficiencies Using Benzothiazole and Xanthene Dyes as Acid Sensors," Chemistry Materials, Vol. 9, No. 12, 1997, pp. 3222-3230. http://dx.doi.org/10.1021/cm970587p

[13] C. G. Knight and T. Stephens, "Xanthene-Dye-Labelled Phosphatidylethanolamines as Probes of Interfacial $\mathrm{pH}$. Studies in Phospholipid Vesicles," Biochemical Journal, Vol. 258, No. 3, 1989, pp. 683-687. http://www.biochemj.org/bj/258/bj2580683.htm

[14] J. Q. Wang and R. G. Harvey, "Synthesis of Polycyclic Xanthenes and Furans via Palladium-Catalyzed Cyclization of Polycyclic Aryltriflate Esters," Tetrahedron, Vol. 58, No. 29, 2002, pp. 5927-5931. http://dx.doi.org/10.1016/S0040-4020(02)00534-3

[15] D. W. Knight and P. B. Little, "The First High-Yielding Benzyne Cyclisation Using a Phenolic Nucleophile: A New Route to Xanthenes," Synlett, No. 10, 1998, pp. 1141-1143. http://dx.doi.org/10.1055/s-1998-1878

[16] G. Casiraghi, G. Casnati and M. Cornia, "Regiospecific Reactions of Phenol Salts: Reaction-Pathways of Alkylphenoxy-Magnesiumhalides with Triethylorthoformate," Tetrahedron Letter, Vol. 14, No. 9, 1973, pp. 679-682. http://dx.doi.org/10.1016/S0040-4039(00)72432-4

[17] A. Jha and J. Beal, "Convenient Synthesis of $12 \mathrm{H}$ Benzo $[a]$ xanthenes from 2-Tetralone," Tetrahedron Letter, Vol. 45, No. 29, 2004, pp. 8999-9001. http://dx.doi.org/10.1016/j.tetlet.2004.10.046

[18] F. Shirini, M. Abedini and R. Pourhasan, " $N$-Sulfonic Acid Poly(4-Vinylpyridinium) Chloride: A Novel Polymeric and Reusable Catalyst for the Preparation of Xanthenes Derivatives," Dyes and Pigments, Vol. 99 No. 1, 2013, pp. 250-255.

http://dx.doi.org/10.1016/j.dyepig.2013.04.036

[19] Z. Zhou and X. Deng, " $\left[\mathrm{Et}_{3} \mathrm{NH}\right]\left[\mathrm{HSO}_{4}\right]$ Catalyzed Efficient and Green Synthesis of 1,8-Dioxo-Octahydroxanthenes," Journal of Molecular Catalysis A: Chemical, Vol. 367, 2013, pp. 99-102.

http://dx.doi.org/10.1016/j.molcata.2012.11.002

[20] H. A. Soliman and T. A. Salama, "Silicon-Mediated Highly Efficient Synthesis of 1,8-Dioxo-Octahydroxanthenes and Their Transformation to Novel Functionalized Pyrano- 
Tetrazolo[1,5-a] Azepine Derivatives," Chinese Chemical Letters, Vol. 24, No. 5, 2013, pp. 404-406. http://dx.doi.org/10.1016/j.cclet.2013.03.021

[21] M. Khoshnevis, A. Davoodnia, A. Z. Bidaki and N. T. Hoseini, "Alumina Supported Acidic Ionic Liquid: Preparation, Characterization, and Its Application as Catalyst in the Synthesis of 1,8-Dioxo-Octahydroxanthenes," Synthesis and Reactivity in Inorganic, Metal-organic and Nano-Metal Chemistry, Vol. 43, No. 9, 2013, pp. 11541161. http://dx.doi.org/10.1080/15533174.2012.756897

[22] A. John, P. J. P. Yadav and S. J. Palaniappan, "Clean Synthesis of 1,8-Dioxo-Dodecahydroxanthene Derivatives Catalyzed by Polyaniline- $P$-Toluenesulfonate Salt in Aqueous Media," Journal of Molecular Catalysis A: Chemical, Vol. 248, No. 1-2, 2006, pp. 121-125. http://dx.doi.org/10.1016/j.molcata.2005.12.017

[23] A. Pramanik and S. Bhar, "Alumina-Sulfuric Acid Catalyzed Eco-Friendly Synthesis of Xanthenediones," $\mathrm{Ca}$ talysis Communication, Vol. 20, 2012, pp. 17-24. http://dx.doi.org/10.1016/j.catcom.2011.12.036

[24] N. Mulakayala, G. Pavan Kumar, D. Rambabu, M. Aeluri, M. V. B. Rao and M. Pal, "A Greener Synthesis of 1,8Dioxo-Octahydroxanthene Derivatives under Ultrasound," Tetrahedron Letter, Vol. 53, No. 51, 2013, pp. 6923-6926. http://dx.doi.org/10.1016/i.tetlet.2012.10.024

[25] K. Moghadam and S. C. Azimi, " $\mathrm{Mg}\left(\mathrm{BF}_{4}\right)_{2}$ Doped in [BMIm] $\left[\mathrm{BF}_{4}\right]$ : A Homogeneous Ionic Liquid-Catalyst for Efficient Synthesis of 1,8-Dioxo-Octahydroxanthenes, Decahydroacridines and 14-Aryl-14H-Dibenzo[a,j]Xanthenes," Journal Molecular Catalysis A: Chemical, Vol. 363-364, 2012, pp. 465-469.

http://dx.doi.org/10.1016/j.molcata.2012.07.026

[26] N. Mulakayala, P. V. N. S. Murthy, D. Rambabu, M. Aeluri, R. Adepu, G. R. Krishna, C. M. Reddy, K. R. S. Prasad, M. Chaitanya, C. S. Kumar, M. V. Basaveswara Rao and M. Pal, "Catalysis by Molecular Iodine: A Rapid Synthesis of 1,8-Dioxo-Octahydroxanthenes and Their Evaluation as Potential Anticancer Agents," Bioorganic \& Medicinal Chemistry Letters, Vol. 22, No. 6, 2012, pp. 2186-2191. http://dx.doi.org/10.1016/j.bmcl.2012.01.126

[27] A. Zare, A. R. Moosavi-Zare, M. Merajoddin, M. A. Zolfigol, T. Hekmat-Zadeh, A. Hasaninejad, A. Khazaei, M. Mokhlesi, V. Khakyzadeh, F. Derakhshan-Panah, M. H. Beyzavi, E. Rostami, A. Arghoon and R. Roohandeh, "Ionic Liquid Triethylamine-Bonded Sulfonic Acid $\left\{\left[\mathrm{Et}_{3} \mathrm{~N}\right.\right.$ $\left.\left.\mathrm{SO}_{3} \mathrm{H}\right] \mathrm{Cl}\right\}$ as a Novel, Highly Efficient and Homogeneous Catalyst for the Synthesis of $\beta$-Acetamido Ketones, 1,8Dioxo-Octahydroxanthenes and 14-Aryl-14H-Dibenzo[a,j] Xanthenes," Journal of Molecular Liquids, Vol. 167, 2012, pp. 69-77. http://dx.doi.org/10.1016/j.molliq.2011.12.012

[28] P. Pradeep, J. Shrinivasa Rao and J. Shubha, "DABCO Promoted Multi-Component One-Pot Synthesis of Xanthenederivatives," Research Journal of Chemical Sciences, Vol. 2, No. 8, 2012, pp. 21-25.

http://www.isca.in/rjcs/Archives/vol2/i8/4.ISCA-RJCS-2 012-088.pdf

[29] A. Llangovan, S. Malayappasamy, S. Muralidharan and S. Maruthamuthu, "A Highly Efficient Green Synthesis of 1,8-Dioxo-Octahydroxanthenes," Chemistry Central Journal, Vol. 5, 2011.
http://dx.doi.org/10.1186/1752-153X-5-81

[30] H. A. Oskooie, L. Tahershamsi, M. M. Heravi and B. Baghernejad, "Cellulose Sulfonic Acid: An Efficient Heterogeneous Catalyst for the Synthesis of 1, 8-Dioxo-Octahydroxanthenes," E-Journal of Chemistry, Vol. 7, No. 3, 2010, pp. 717-720.

http://dx.doi.org/10.1155/2010/936107

[31] G. Karthikeyan and A. Pandurangan, "Heteropolyacid $\left(\mathrm{H}_{3} \mathrm{PW}_{12} \mathrm{O}_{40}\right)$ Supported MCM-41: An Efficient Solid Acid Catalyst for the Green Synthesis of Xanthenedione Derivatives," Journal Molecular Catalysis A: Chemical, Vol. 311, No. 1-2, 2009, pp. 36-45. http://dx.doi.org/10.1016/j.molcata.2009.06.020

[32] K. Niknam and M. Damya, "1-Butyl-3-Methylimidazolium Hydrogen Sulfate [Bmim] $\mathrm{HSO}_{4}$ : An Efficient Reusable Acidic Ionic Liquid for the Synthesis of 1,8-Dioxo-Octahydroxanthenes," Journal of the Chinese Chemical Society, Vol. 56, No. 3, 2009, pp. 659-665.

[33] H. R. Shaterian, A. Hosseinian and M. Ghashang, "Ferric Hydrogen Sulfate as an Efficient Heterogeneous Catalyst for Environmentally Friendly Greener Synthesis of 1,8Dioxo-Octahydroxanthenes," Turkish Journal of Chemistry, Vol. 33, No. 2, 2009, pp. 233-240.

[34] K. Vankatesan, S. S. Pujari, R. J. Lahoti and K. V. Srinivasan, "An Efficient Synthesis of 1,8-Dioxo-OctahydroXanthene Derivatives Promoted by a Room Temperature Ionic Liquid at Ambient Conditions under Ultrasound Irradiation," Ultrasonic Sonochemistry, Vol. 15, No. 4, 2008, pp. 548-553.

http://dx.doi.org/10.1016/j.ultsonch.2007.06.001

[35] H. N. Karade, M. Sathe and M. P. Kaushik, "An Efficient Synthesis of 1, 8-Dioxo-Octahydroxanthenes Using Tetrabutylammonium Hydrogen Sulfate," ARKIVOC, Vol. xiii, 2007, pp. 252-258. http://dx.doi.org/10.3998/ark.5550190.0008.d28

[36] A. Rahmati, "A Rapid and Efficient Method for the Synthesis of $14 H$-Dibenzo[ $\alpha . j]$ Xanthenes, Aryl-5H-Dibenzo [b.i]xanthene-5,7,12,14-(13H)-Tetraone and 1,8-Dioxo-Octahydroxanthenes by Acidic Ionic Liquid," Chinese Chemical Letter, Vol. 21, No. 7, 2010, pp. 761-764. http://dx.doi.org/10.1016/i.cclet.2010.02.014

[37] D. Fang, J. Yang and Z. Liu, "Eco-Friendly Synthesis of 1,8-Dioxo-Octahydroxanthenes Catalyzed by Ionic Liquid in Aqueous Media," Journal of Heterocyclic Chemistry, Vol. 48, No. 2, 2011, pp. 468-472.

http://dx.doi.org/10.1002/jhet.543

[38] D. Fang, K. Gong and Z. Liu, "Synthesis of 1,8-DioxoOctahydroxanthenes Catalyzed by Acidic Ionic Liquids in Aqueous Media," Catalysis Letters, Vol. 127, No. 3-4, 2009, pp. 291-295. http://dx.doi.org/10.1007/s10562-008-9677-0

[39] M. Dabirir, M. Baghbanzadeh and E. Arzroomchilar, "1-Methylimidazolium triflouroacetate ([Hmim]TFA): An Efficient Reusable Acidic Ionic Liquid for the Synthesis of 1,8-Dioxo-Octahydroxanthenes and 1,8-Dioxo-Decahydroacridines," Catalysis Communications, Vol. 9, No. 5, 2008, pp. 939-942.

http://dx.doi.org/10.1016/j.catcom.2007.09.023

[40] M. A. Bigdeli, F. Nemati, G. H. Mahdavinia and H. Doo- 
stmohammadi, "A Series of 1,8-Dioxooctahydroxanthenes Are Prepared Using Trichloroisocyanuric Acid," Chinese Chemical Letters, Vol. 20, No. 11, 2009, pp. 1275-1278. http://dx.doi.org/10.1016/j.cclet.2009.06.024

[41] Z. H. Zhang and Y. H Liu, "Antimony Trichloride/ $\mathrm{SiO}_{2}$ Promoted Synthesis of 9-Ary-3,4,5,6,7,9-Hexahydroxanthene-1,8-Diones," Catalysis Communications, Vol. 9, No. 8, 2008, pp. 1715-1719. http://dx.doi.org/10.1016/j.catcom.2008.01.031

[42] G. H. Mahdavinia, M. A. Bigdeli and Y. S. Hayeniaz, "Covalently Anchored Sulfonic Acid on Silica Gel $\left(\mathrm{SiO}_{2}-\mathrm{R}-\mathrm{SO}_{3} \mathrm{H}\right)$ as an Efficient and Reusable Heterogeneous Catalyst for the One-Pot Synthesis of 1,8-DioxoOctahydroxanthenes Under Solvent-Free Conditions," Chinese Chemical Letters, Vol. 20, No. 5, 2009, pp. 539541. http://dx.doi.org/10.1016/j.cclet.2008.12.026

[43] G. K. Verma, K. Raghuvanshi, R. K. Verma, P. Dwivedi and M. S. Singh, "An Efficient One-Pot Solvent-Free Synthesis and Photophysical Properties of 9-Aryl/Alkyl-Octahydroxanthene-1,8-Diones," Tetrahedron, Vol. 67, No. 20, 2011, pp. 3698-3704. http://dx.doi.org/10.1016/j.tet.2011.03.078

[44] T. S. Jin, J. S. Zhang, J. C. Xiao, A. Q. Wang and T. S. Li, "Clean Synthesis of 1,8-Dioxo-octahydroxanthene Derivatives Catalyzed by $p$-Dodecylbenezenesulfonic Acid in Aqueous Media," Synlett, No. 5, 2004, pp. 866-870. http://dx.doi.org/10.1055/s-2004-820022

[45] X. S. Wang, D. Q. Shi, Y. L. Li, H. Chen, X. Y. Wei and Z. M. Zong, "A Clean Synthesis of 1 - Oxo - hexahydroxanthene Derivatives in Aqueous Media Catalyzed by TEBA," Synthetic Communications, Vol. 35, No. 1, 2005, pp. 97-104. http://dx.doi.org/10.1081/SCC-200046510

[46] F. Darvish, S. Balalaei, F. Chadegani and P. Salehi, "Diammonium Hydrogen Phosphate as a Neutral and Efficient Catalyst for Synthesis of 1,8 - Dioxo - Octahydroxanthene Derivatives in Aqueous Media," Synthetic Communications, Vol. 37, No. 7, 2007, pp. 1059-1066. http://dx.doi.org/10.1080/00397910701196520

[47] S. Kantevari, R. Bantu, L. Nagarapu, " $\mathrm{HClO}_{4}-\mathrm{SiO}_{2}$ and PPA-SiO ${ }_{2}$ Catalyzed Efficient One-Pot Knoevenagel Condensation, Michael Addition and Cyclo-Dehydration of Dimedone and Aldehydes in Acetonitrile, Aqueous and solvent Free Conditions: Scope and Limitations," Journal of Molecular Catalysis A: Chemical, Vol. 269, No. 1-2, 2007, pp. 53-57. http://dx.doi.org/10.1016/j.molcata.2006.12.039

[48] M. Dabiri, S. C. Azimi and A. Bazgir, "One-Pot Synthesis of Xanthene Derivatives under Solvent-Free Conditions," Chemical Papers, Vol. 62, No. 5, 2008, pp. 522-526. http://dx.doi.org/10.2478/s11696-008-0050-y

[49] G. Y. Song, B. Wang, H. Luo and L. Yang, "Fe ${ }^{3+}$-Mont- morillonite as a Cost-Effective and Recyclable Solid Acidic Catalyst for the Synthesis of Xanthenediones," Catalysis Communication, Vol. 8, No. 4, 2007, pp. 673-676. http://dx.doi.org/10.1016/j.catcom.2005.12.018

[50] S. Kantevari, R. Bantu and L. Nagarapu, ARKIVOC Part (xvi), 2006, pp. 136-148.

[51] B. Dashttp, P. Thirupathi, K. R. Reddy, B. Ravikanth and L. Nagarapu, "An Efficient Synthesis of 1,8-Dioxo-Octahydroxanthenes Using Heterogeneous Catalysts," Catalysis Communications, Vol. 8, No. 3, 2007, pp. 535-538. http://dx.doi.org/10.1016/j.catcom.2006.02.023

[52] M. T. Maghsoodlou, S. M. Habibi-Khorassani, Z. Shahkarami, N. Maleki and M. Rostamizadeh, "An Efficient Synthesis of 2,2'-Arylmethylene Bis(3-Hydroxy-5,5-Dimethyl-2-Cyclohexene-1-One) and 1,8-Dioxo-Octahydroxanthenes Using $\mathrm{ZnO}$ and $\mathrm{ZnO}$-Acetyl Chloride," Chinese Chemical Letters, Vol. 21, No. 6, 2010, pp. 686-689. http://dx.doi.org/10.1016/j.cclet.2010.02.005

[53] P. Srihari, S. S. Mandal, J. S. S. Reddy and R. S. Rao and J. S. Yadav, "Synthesis of 1,8-Dioxo-Octahydroxanthenes Utilizing PMA-SiO $\mathrm{P}_{2}$ as an Efficient Reusable Catalyst," Chinese Chemical Letters, Vol. 19, No. 7, 2008, pp. 771774. http://dx.doi.org/10.1016/j.cclet.2008.05.005

[54] H. Y. Lü, J. J. Li and Z. H. Zhang, " $\mathrm{ZrOCl}_{2} \cdot 8 \mathrm{H}_{2} \mathrm{O}$ : A Highly Efficient Catalyst for the synthesis of 1,8-DioxoOctahydroxanthene Derivatives under Solvent-Free Conditions," Applied Organometalic Chemistry, Vol. 23, No. 4, 2009, pp. 165-169. http://dx.doi.org/10.1002/aoc.1488

[55] B. Das, P. Thirupathi, I. Mahender, V. S. Reddy and Y. K. Rao, "Amberlyst-15: An Efficient Reusable Heterogeneous Catalyst for the Synthesis of 1,8-Dioxo-Octahydroxanthenes and 1,8-Dioxo-Decahydroacridinesao," Journal of Molecular Catalysis A: Chemical, Vol. 247, No. 1-2, 2006, pp. 233-239.

http://dx.doi.org/10.1016/j.molcata.2005.11.048

[56] G. I. Shakibaei, P. Mirzaei and A. Bazgir, "Dowex-50W Promoted Synthesis of 14-aryl-14H-Dibenzo[ $a, j]$ xanthene and 1,8-Dioxo-Octahydroxanthene Derivatives Under Solvent-Free Conditions," Applied Catalysis A: General, Vol. 325, No. 1, 2007, pp. 188-192.

http://dx.doi.org/10.1016/j.apcata.2007.03.008

[57] P. Wasserscheid and T. Welton, "In Ionic Liquids in Synthesis," Vols.1 and 2, 2nd Edition, Wiley-VCH, Weinheim, 2008.

[58] X.-D. Wang, W.-Y. Wu, G.-F. Tu and K.-X. Jiang, "Synthesis and Physico-Chemical Properties of New Green Electrolyte 1-Butyl-3-Methylimidazolium Perchlorate," Transactions of Nonferrous Metals Society of China, Vol. 20, No. 10, 2010, pp. 2032-2036.

http://dx.doi.org/10.1016/S1003-6326(09)60413-1 